Bangladesh J. Plant Taxon. 20(2): 201-205, 2013 (December)

(C) 2013 Bangladesh Association of Plant Taxonomists

\title{
A NEW RANUNCULUS SPECIES (RANUNCULACEAE) FROM SHAANXI, CHINA
}

\author{
Min-Rong LuO ${ }^{1}$ AND Liang ZhaO ${ }^{2}$ \\ College of Life Sciences, Northwest A\&F University, Yangling, Shaanxi, 712100, China
}

Keywords: Ranunculus shanyangensis; New species; China.

\begin{abstract}
Ranunculus shanyangensis M.R. Luo \& L. Zhao, a new species of Ranunculaceae from Shaanxi, China, is described and illustrated. Ranunculus shanyangensis is morphologically similar to $R$. repens, however, it differs from the latter due to the following characters: longer adventitious roots, wholly creeping stems with no branches, longer rachis, fewer floral organs and pollen wall sculpturing. SEM micrography of the pollens for $R$. shanyangensis and $R$. repens are presented along with distribution map.
\end{abstract}

\section{Introduction}

Ranunculus is the largest genus within Ranunculaceae including about 600 species, primarily distributed in temperate to arctic or subantarctic zones, but a few species are also found in high montane regions of the tropics (Tamura, 1995). Wang and Gilbert (2001) revised the genus Ranunculus in China and recognized 125 species in China, of which 66 are endemic.

When we were carrying out a fieldwork survey in May 2009 in Shaanxi Province, China, we came across a distinct population of Ranunculus. This population grew in slightly moist region in the Qinling Mountains. Notable morphological characteristics that distinguish this population from other species include longer adventitious roots, longer rachis, wholly creeping stems that lack branches and fewer floral organs. Based on literature review (Davis, 1965; Timokhina, 1993; Tutin, 1993; Whittemore, 1997; Wang and Gilbert, 2001; Kadoto, 2006; Tzvelev, 2007) and examination of specimens from several herbaria, we have determined that individuals of this population are similar to $R$. repens L. However, combination of characteristics distinguishes this population as new species, $R$. shanyangensis. Here we describe this new species.

\section{Materials and Methods}

The specimens of Ranunculus repens from several herbaria (PE, WUK, NAS, IFP, LBG, IBSC, IBK) have been examined representing collections made in China as well as Europe and North America. Flowers and fruits were rehydrated and measurements were taken for each character.

Palynological investigation was conducted to determine whether unique characteristics were present in $R$. shanyangensis. Pollen samples were obtained from dried herbarium specimens and suspended in distilled water, after acetolysis, fixed on SEM specimen holders, which had been cleaned with acetone. The specimens were sputter-coated with gold for $1.5 \mathrm{~min}$ and photographed using a Hitachi S-4800 scanning electron microscope. Palynological terminology follows Santisuk (1979).

\footnotetext{
${ }^{1}$ College of Horticulture, Northwest A\&F University, Yangling, Shaanxi, 712100, China

${ }^{2}$ Corresponding author. Email: biology_zhaoliang@126.com
} 
Ranunculus shanyangensis M.R. Luo \& L. Zhao sp. nov.

(Figs 1, 3).

Diagnosis: Species nova $R$. repenti $L$. similis est, a quo caule toto tranversaliter repente, simplice, flaccido, ad nodos radicante, radicibus tenuibus, $5-10 \mathrm{~cm}$ longis, pedunculo longiore 13$15 \mathrm{~cm}$ longo, staminibus 35-40 per florem, granis pollenis pantocolpatis, carpellis 15-20 differt.

Type: Shanyang County, Shaanxi Province, North-west China; altitude $1100 \mathrm{~m} ; 33^{\circ} 25^{\prime} 20^{\prime \prime} \mathrm{N}$, $110^{\circ} 08^{\prime} 00^{\prime E} \mathrm{E}, 15$ May 2009, Liang Zhao 20090501 (Holotype: WUK; Isotype: WUK, PE).

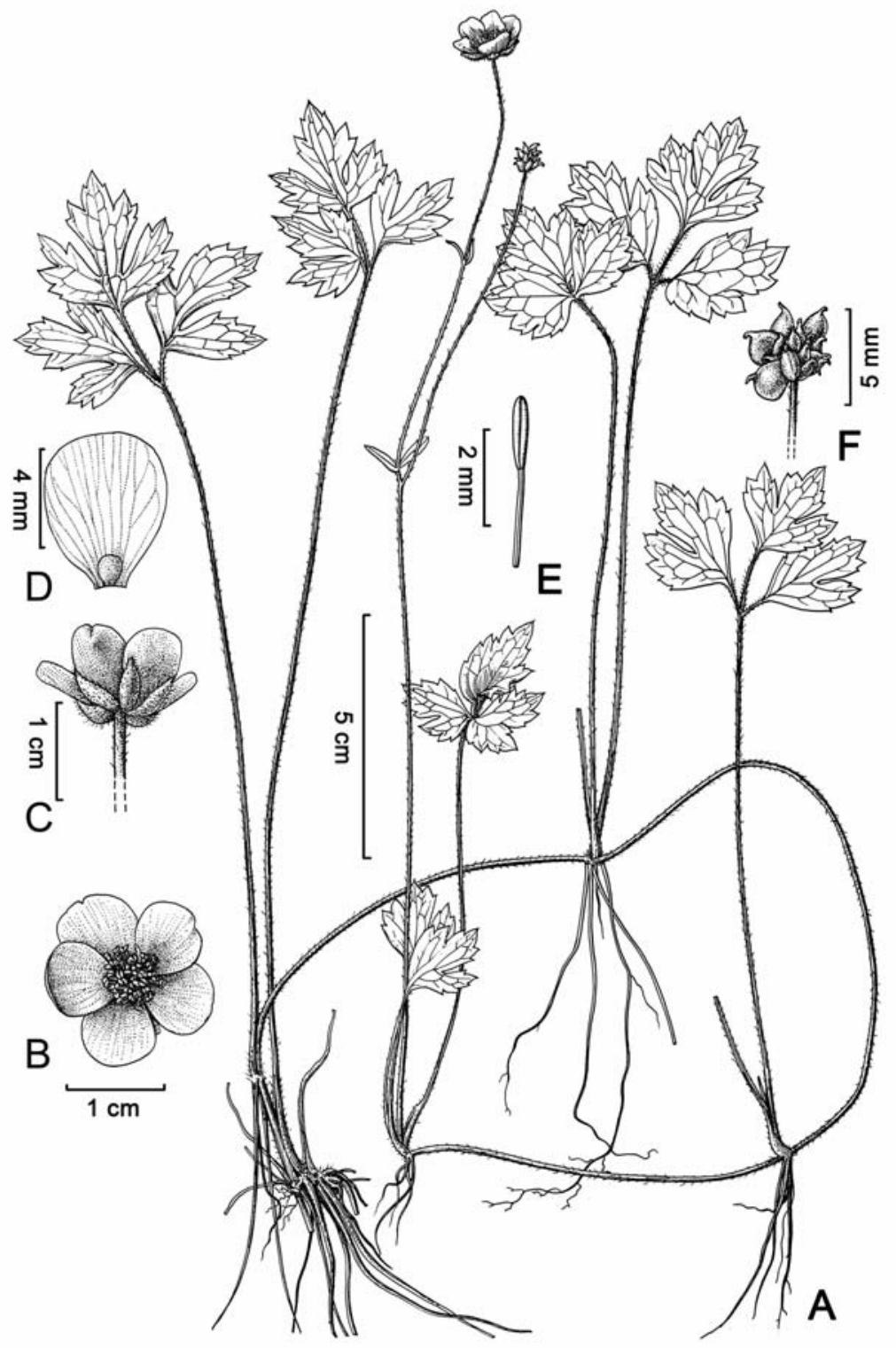

Fig. 1. Ranunculus shanyangensis M.R. Luo \& L. Zhao sp. nov. (A) Habit, (B) Flower - apical view, (C) Flower - lateral view, (D) Petal, (E) Stamen, (F) Fruit. 
Perennial herbs. Adventitious roots $5-10 \mathrm{~cm}$ long. Stems wholly creeping, 20-50 cm long, slender, c. 1.0-1.2 $\mathrm{mm}$ in diameter, hirsute, rooting at the nodes, old petiole persistent on nodes. Leaves mostly basal, or in nodes of stolons (2-4); petiole 5-18 cm long; blade ternate, reniform to pentagonal; both surfaces hirsute; central leaflet broadly rhombic, 2.0-2.6 $\times 2.0-2.5 \mathrm{~cm}$; base broadly cuneate, secondary lobes lobed or partite; lateral leaflets oblique, unequally 2- or 3-lobed or partite; petiolule $0.5-2.0 \mathrm{~cm}$ long. Cauline leaves smaller. Flowers (1-2) in loose cyme, axillary; rachis $13-15 \mathrm{~cm}$ long; bracts 3-lobed or undivided, lanceolate to linear. Flowers $1.4-1.7 \mathrm{~cm}$ in diameter; pedicels 5-7 cm long, hirsute. Receptacle hirsute. Sepals 5.5-6.0 $\times 2-4 \mathrm{~cm}$, navicular at anthesis, hirsute on abaxial surface. Petals 5-8 $\times 4-5 \mathrm{~mm}$, obovate or widely obovate; claw $1 \mathrm{~mm}$ long; nectary covered by a scale, c. $1 \mathrm{~mm}$ long. Stamens $35-40$; anthers c. $1.5 \mathrm{~mm}$ long; filaments c. $2.0 \mathrm{~mm}$ long. Carpels $15-20$. Achene bilaterally compressed, obliquely obovate, c. $2.2 \times 2.0 \mathrm{~mm}$, glabrous, narrowly marginate; beak c. $0.5 \mathrm{~mm}$ long.

Phenology: It sprouts in late February, and the aboveground parts die in early November. Flowering occurs in May - August and fruiting in June - September.

Specimens examined: Shaanxi, Shanyang County, in slightly moist areas, 1100 m, 15 May 2009, Liang Zhao 20090502 (SANU); ibid., 1105 m, Liang Zhao 20090503 (SANU ), Liang Zhao 20090504 (SANU), Liang Zhao 20090505 (SANU ), Liang Zhao 20090506 (SANU ), Liang Zhao 20090507 (SANU ), Liang Zhao 20090508 (SANU ); ibid., Liang Zhao 20090509(PE), Liang Zhao 20090510 (PE).

Distribution: Ranunculus shanyangensis is found in the moist area in Shanyang County, Shaanxi Province, North-west China (Fig. 2). Recent observations suggest that the population of this new species has a narrow geographic distribution, and possibly endemic to this site. After intensive field investigation in Qinling Mountains from 2009 to 2010, we only found one population with about 200 individuals.

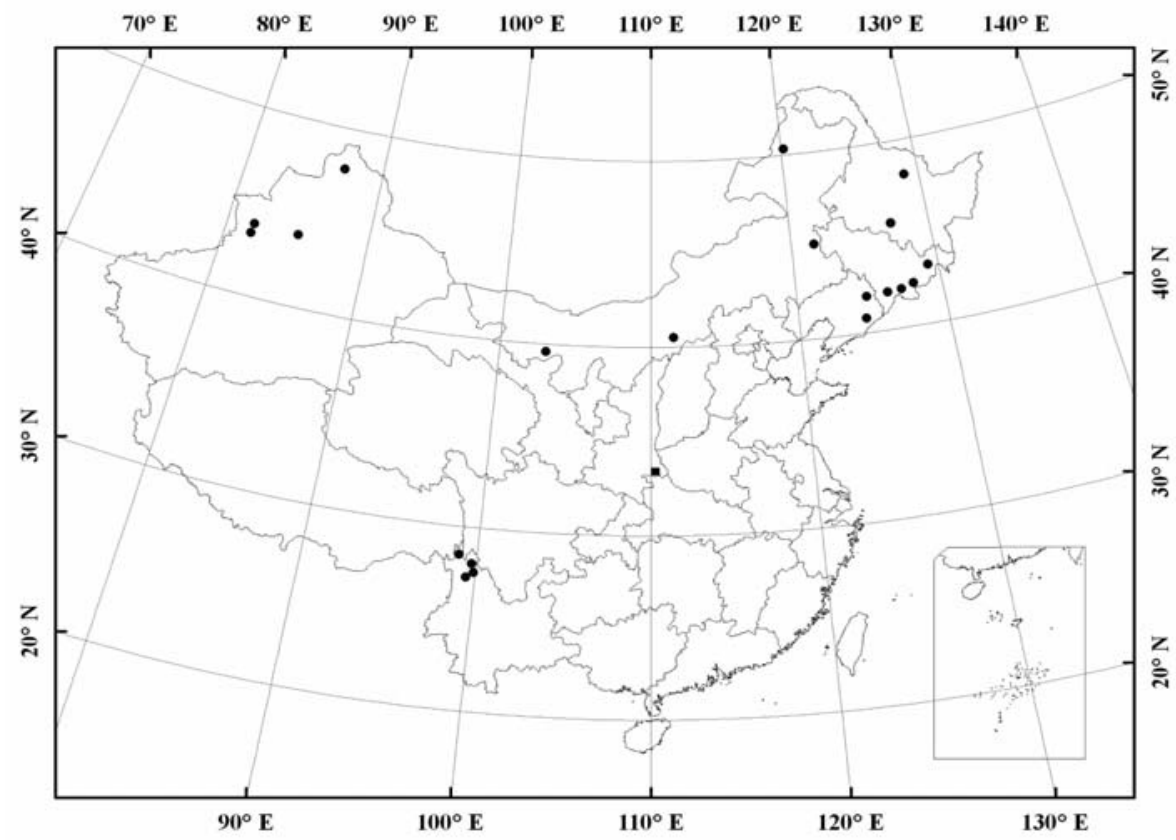

Fig. 2. Distribution of Ranunculus repens (•) and R. shanyangensis ( $\mathbf{\bullet})$ in China. 
Conservation status: Using the IUCN categories and criteria (IUCN, 2001), we suggest ranking of Ranunculus shanyangensis as 'Critically Endangered' (CR), which is based on the size of this population and its close proximity to urban and agricultural areas.

Etymology: The specific epithet refers to Shanyang County where the type collections were made.

Notes: Ranunculus shanyangensis is morphologically similar and possibly closely related to $R$. repens L. Both have creeping stems, rooting at the nodes; smooth, bilaterally compressed and narrowly marginate achenes; and the petal nectary pit is covered by a scale. However, $R$. shanyangensis differs from $R$. repens in adventitious root $(5-10 \mathrm{~cm}$ vs. $1-3 \mathrm{~cm}$ ), stem (wholly creeping, no branched vs. ascending or suberect, branched above), rachis $(13-15 \mathrm{~cm}$ vs. $5-8 \mathrm{~cm})$, stamens (35-40 vs. c. 50$)$, carpels (15-20 vs. $30-35)$ and pollen (stephanocolpate vs. tricolpate) characters.

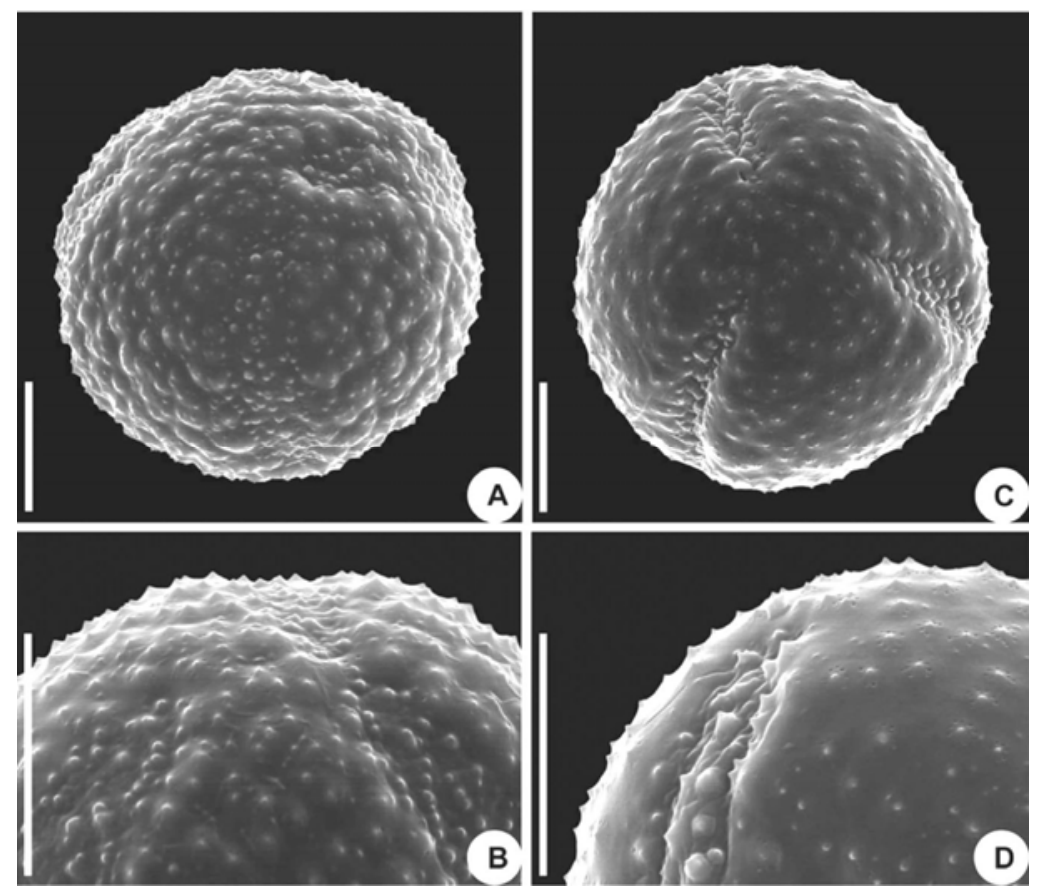

Fig. 3. Pollen morphology under scanning electron microscopy (SEM). (A, B) Ranunculus shanyangensis, (C, D) R. repens. Scale bar: A, B, C, D = $10 \mu \mathrm{m}$

Pollen morphology:

In our examination of the pollen in R. repens from China, Europe and North America, we note that all of them are tricolpate (Fig. 3C) with small and sparsely spaced spinules (Fig. 3D). This character is in accord with the results of Erdtman et al. (1961), whose material was collected from Scandinavia. However, the pollen of Ranunculus shanyangensis is pantocolpate (Fig. 3A) and bears densely spaced spinules (Fig. 3B).

\section{Acknowledgements}

We are grateful to Professor Wen-Tsai Wang, Institute of Botany, Chinese Academy of Sciences, China for his help. We thank Dr. Mare Nazaire, Washington State University, United 
States, and Dr. Jeremy Lundholm, Saint Mary's University, Canada for their helpful comments and correcting the English. We also thank Mr. Yin-Hou Xiao for his assistance in taking SEM photographs. This project was supported by the Fundamental Research Funds for the Central Universities (No. QN2012020), the Specialized Research Fund for the Doctoral Program of Higher Education of China (No. 20120204120032) and the National Natural Science Foundation of China (31300158 and 31100141).

\section{References}

Davis, P.H. 1965. Ranunculus L. In: Davis, P.H. (Ed.), Flora of Turkey. Vol. 1. Edinburgh University Press, pp. 146-197.

Erdtman, G., Berglund, B. and Praglowski, J. 1961. An introduction to a Scandinavian pollen flora. Grana 2: $1-92$.

IUCN 2001. IUCN red list categories and criteria, version 3.1. IUCN Species Survival Commission, Switzerland.

Kadoto, Y. 2006. Ranunculus L. In: Iwatsuki, K., Boufford, D.E. and Ohba, H. (Eds), Flora of Japan. Vol. 2(a). Kodansha, Tokyo, pp. 310-322.

Santisuk, T. 1979. A palynological study of the tribe Ranunculeae. Opera Bot. 48: 1-74.

Tamura, M. 1995. Ranunculaceae. In: Hiepko, P. (Ed.), Die Natürlichen Pflanzenfamilien, 2nd ed. Vol. 17a (4). Duncker und Humblot, Berlin, pp. 1-556.

Timokhina, S.A. 1993. Ranunculus L. In: Malyschev, L.I. and Peschkova, G.A. (Eds), Flora of Siberia. Vol. 6. Science Publishers, Inc., Enfield, NH, USA, pp. 162-195.

Tutin, T.G. 1993. Ranunculus L. In: Tutin, T.G., Burges, N.A., Chater, A.O., Edmondson, J.R., Heywood, V.H., Moore, D.M., Valentine, D.H., Walters, S.M. and Webb, D.A. (Eds), Flora Europaea. Vol. 1. 2nd edition. Cambridge University Press, pp. 269-186.

Tzvelev, N.N. 2007. Ranunculus L. In: Tzvelev, N.N. (Ed.), Flora of Russia. Vol. 10(a). Taylor and Francis / Balkema. AK Leiden, The Netherlands. pp. 116-188.

Wang, W.T. and Gilbert, M.G. 2001. Ranunculus L. In: Wu, Z.Y., Raven, P.H. and Hong, D.Y. (Eds), Flora of China. Vol. 6. Science Press \& Missouri Botantical Garden Press. pp. 391-431.

Whittemore, A.T. 1997. Ranunculus L. In: Flora of North America Editorial Committee, Flora of North America. Vol. 3. Oxford University Press, pp. 88-134.

(Manuscript received on 30 March 2013; revised on 11 October 2013) 